\title{
Cycling diversity, accessibility, and equality: an analysis of cycling commuting in Bogotá
}

\author{
Daniel Rosas-Satizábal, MSc. Corresponding Author \\ Transport Consultant \\ IDOM Consulting, Engineering, Architecture S.A.U., Colombia \\ Sostenibilidad Urbana y Regional (SUR) Research Group, School of Engineering, Universidad de \\ los Andes \\ Carrera 1E N 19A-40, Bogotá, Colombia \\ Tel: +57.1.339.4949; Email: dr.rosas10@uniandes.edu.co
}

\section{Luis A. Guzman, PhD}

Associated Professor

Department of Civil and Environmental Engineering

Universidad de los Andes

Carrera 1E N 19A-40, Bogotá, Colombia

Tel: +57.1.339.4949; Email: 1a.guzman@uniandes.edu.co

\section{Daniel Oviedo, PhD}

Assistant Professor

Development Planning Unit

University College London

34 Tavistock Square, London WC1H 9EZ, UK

Tel: + 44 (0)20 7679 5584; Email: daniel.oviedo@ucl.ac.uk 


\begin{abstract}
In a context of rising awareness for environmental concerns and promotion policies targeting nonmotorized travel as a sustainable mobility solution, the bicycle has increasingly become an attractive transport mode in cities. However, accessibility to opportunities for people who cycle is not necessarily the same across socioeconomically different population segments, and it tends to be further constrained by high costs associated with the travel distance through the road network. This research examines equality in the accessibility to employment and education among cycleuser adults in Bogotá. Using 968 reported bicycle trips with these travel purposes in the 2015 Bogotá Household Travel Survey, we estimate a potential accessibility indicator and horizontal and vertical equality indicators. First, we identify three clusters through the K-prototypes method to classify bicycle commuters based on trip and socioeconomic characteristics, and second, we calculate potential accessibility using GIS-based trip distance decay functions, which is later assessed through equality indices such as Lorenz Curves, Gini index and Palma Ratio. Results show marked differences in potential accessibility to work and study opportunities between and within clusters, where up to $90 \%$ of the analyzed population of a cyclists' cluster has access to $30 \%$ of the job and study opportunities, indicating social and spatial inequalities produced by the urban structure and individual and household characteristics of regular cyclists. Results can guide in the implementation of accurate transport policies towards more equitable and sustainable transport in cities that are experiencing increases in bicycle ridership.
\end{abstract}

Keywords: Urban cycling; potential accessibility; bicycle accessibility; cluster analysis; equality; Bogotá. 


\section{Introduction}

This paper identifies statistically different cyclist groups, their individual and travel behavior characteristics to evaluate the distribution of cycling accessibility to work and education opportunities in segregated urban areas. The empirical context of this analysis is Bogotá, Colombia's capital and a recurrent case study in recent literature addressing social and spatial inequalities in urban transport, and a paradigmatic case of urban transport and infrastructure policies in the Global South. This paper contributes to current debates at the global and local scale related to sustainable urban mobility transitions, planning for accessibility and distributional effects of active mobility.

Cycling is gaining ground as a feasible alternative for urban mobility in cities across the world. Factors associated with rapid cycling uptake are its sustainable and affordable nature, particularly for short and middle distances. Advocates of cycling-as-commuting present it as a money-saving and healthy alternative to avoid traffic congestion (Handy et al., 2014; Pucher et al., 2010; Sallis et al., 2004), which brings overall economic benefits and positive externalities to society (Blondiau et al., 2016). Local governments are increasingly promoting cycling in their communities, aligning themselves with global interest in meeting the Sustainable Development Goals (SDG). Focusing on SDG's 3, 10, and 11, equal access to safe and reliable forms of transport is a crucial element for healthy, equality and accessible cities. Since traveling poses a means to reach basic needs and economic benefits, the transport system and mode planning should encourage this transport equality. Recent bicycle promotion in cities is often limited to the provision of cycling infrastructure with no specific policies targeting equality among cyclists. 
In Latin American cities, where social disadvantages play a significant role in determining travel costs -especially for low-income populations-, bicycle ridership has grown rapidly (Rios et al., 2015). In this context, understanding the distribution of access to opportunities across urban geographies and social groups within the cyclist population is relevant for policy and decisionmaking. Unpacking who uses the bicycle and how its use leads to different degrees of accessibility is central in addressing the distributional effects of the adoption of active travel by different socioeconomic groups.

Research in Global South cities regarding accessibility distribution among cyclists is relatively underdeveloped. Previous works examining bicycle accessibility have either focused on cycling as a feeder to public transport (Ortegon-Sanchez and Oviedo Hernandez, 2016) or have not engaged explicitly with its policy dimension. This is illustrated by the assessment of spatial equality for non-motorized modes by Arranz-Lopez et al. (2019). Moreover, there is a small but growing number of studies applying gravity-based accessibility measures for cyclists (McNeil, 2011; Pritchard et al., 2019; Saghapour et al., 2017). Existing literature has not fully addressed the distribution of accessibility to mandatory destinations by bicycle in socially unequal contexts and its implications for urban transport planning.

To differentiate accessibility distribution across population groups, research has relied frequently on clustering methods (Anable, 2005; De Vos et al., 2016; Grisé and El-Geneidy, 2017; Huang et al., 2009; Pritchard et al., 2014). Despite such precedents, cluster configuration using kprototypes applied to accessibility analysis is a recent innovation. It is common to identify income segmentation within cyclist clusters since travel behavior and socioeconomic characteristics (in particular income) have previously been found as controlling variables in the clustering process (Ahmed et al., 2017). Arranz-López et al. (2018) developed a k-modes clustering model to evaluate 
social exclusion risks associated with non-motorized retail trips, finding differences in age and car/bicycle access between four groups in Zaragoza. Pritchard et al. (2019) identified seven statistically different clusters within Sao Paulo cyclists with the main differences being income range and job access (or distance to opportunities) following a geographic clustering methodology. The methodology enabled reaching conclusions such as that accessibility to jobs when riding a bike to public transport stations is better in middle and high-income populations.

To assess inequalities in accessibility distribution, studies have focused on motorized transport modes, assessing inequalities via metrics such as Lorenz curves (Abley et al., 2010; Delbosc and Currie, 2011; Grengs, 2015; Guzman et al., 2017; Guzman and Oviedo, 2018), while others have deployed Gini indices and Palma ratios as ways to quantify the distribution of the positive and negative effects of transport (Ben-Elia and Benenson, 2019; Cao and Hickman, 2019; Lope and Dolgun, 2020; Oviedo and Guzman, 2020; Welch and Mishra, 2013). Research in transport has adopted such methodologies as a recognition that accessibility and the externalities of urban mobility systems are not uniformly distributed across society, placing specific groups at a disadvantage (Kaplan et al., 2014; Ohnmacht et al., 2009; Pereira et al., 2017). In Latin America, a practice-oriented example suggested concepts, indicators, and strategies aiming to position the bicycle as a vehicle to increase urban equality in cities in the region (Rodríguez et al., 2017). However, such indicators have not yet been tested in empirical settings in the region to date. In this context, quantifying and interrogating accessibility-related inequalities for the bicycle -a transport mode essential for sustainable and inclusive urban mobility- becomes a timely subject for research. We build on recent debates on transport and inequalities and consolidated methods and metrics to address the research questions: is bicycle accessibility to job/study equally distributed among cyclists in Bogotá? 
This paper contributes to current debates around the bicycle and the growing social and political interest around it. It calls for the need to understand how cycling accessibility is distributed in contexts where policies and public investments in sustainable transport have sought to increase the number of bicycle commuters. Our research highlights some of the social and economic constraints faced by different population segments for perceiving the bicycle's benefits as a transport mode. The study of cycling accessibility and its implications on equality are relevant issues to address in cities where its use and practical and ideological relevance continue to grow.

\section{Case study: Bogotá}

Bogotá has approximately 7.8 million inhabitants and an urban area of $380 \mathrm{~km}^{2}$ according to estimates from 2015. Bogotá holds a close functional relationship with Soacha, a neighboring municipality with circa 511,000 inhabitants located on the southern edge of Bogotá. This urban area has a segregated urban structure stemming from an unevenly distributed high population density, where low-income residents are far away from jobs and high-education places (Guzman and Bocarejo, 2017), as shown in Figure 1. Opportunities (i.e., jobs and high-education places) match with areas of intense commercial activity and are primarily concentrated around the east edge of the city, where most vertical urban development has taken place. Bogotá's high-capacity public transport, the Bus Rapid Transit (BRT) system, TransMilenio, connects high populated areas with the east section of the city where most opportunities are located. 


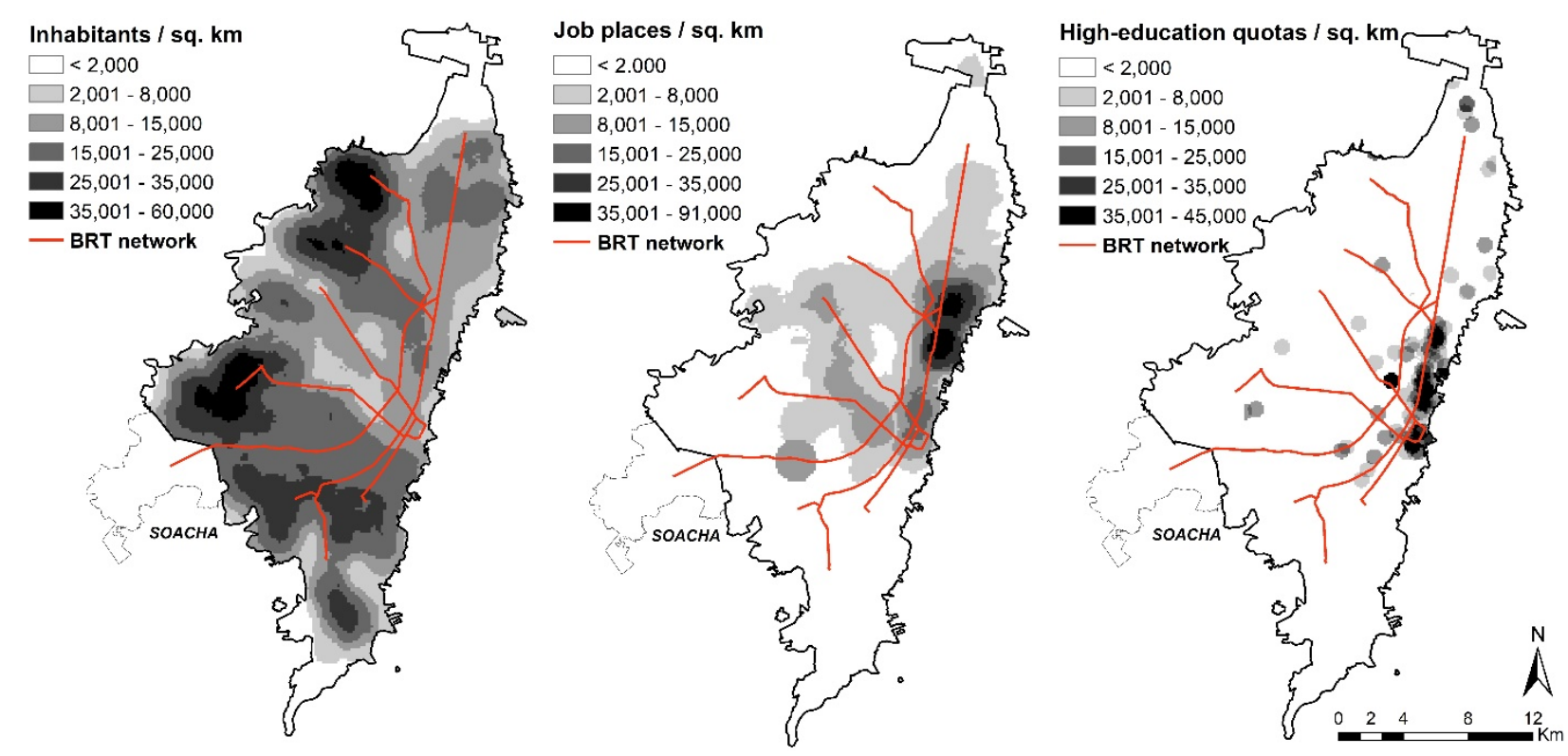

Figure 1 Population, jobs, and study places density in Bogotá and Soacha

Residential areas in Colombia are classified into six different socioeconomic categories numbered from one to six that attempt to reflect characteristics of housing and its surrounding environment, dividing the city into homogeneous physical and economic areas. Such classification is locally known as socioeconomic strata (SES). SES 1 corresponds to housing units of poor quality and lower-income population, and SES 6 to the highest living conditions and characteristics of the built environment. In Bogotá, the low-income population (low SES) is concentrated in the urban periphery, while the high-income population (high SES) is located on the eastern border, where economic opportunities are concentrated. In Soacha, most of the population is classified as lowSES. This distribution of population and economic activities reflects the monocentric land-use patterns in the city, leading to markedly different travel times between socioeconomic groups in public and private motorized modes and producing substantial inequalities in accessibility (Guzman et al., 2017). SES levels and household income are positively correlated in Bogotá, with 
SES 1 matching households with the lowest income and SES 6 matching the highest average income (Cantillo-García et al., 2019).

According to the 2015 Household Travel Survey (HTS) of Bogotá, bicycle trips are mostly short (45\% are less than 15 minutes long) and are mostly associated with travel purposes such as work and study (71.2\%). Moreover, Bogotá has experienced a sustained increase in the number of urban cyclists since the late 1990s and early 2000s (Rios et al., 2015; Rosas-Satizábal and Rodriguez-Valencia, 2019). The mode share of bicycles in the city changed from $0.6 \%$ of all transport modes in 1996 to $4.5 \%$ in the 2015 HTS. A more recent survey applied in 2017 estimated a mode share of $6.5 \%$ for the bicycle (DANE, 2017).

This increase in cycling uptake can be related to, among many other factors, policies targeting cycling infrastructure investment since 1998, which have consolidated a cycling network of $232 \mathrm{~km}$ in 2001, which has increased to $540 \mathrm{~km}$ in 2019. Bogotá boasts the most extensive network of dedicated cycling infrastructure in Latin America (Rios et al., 2015). Figure 2 shows the main road network and the configuration of cycling infrastructure in 2015. Bogotá's cycling infrastructure can be loosely classified in off-street bike-paths $(347 \mathrm{~km}$, of which almost $300 \mathrm{~km}$ are sharing space with pedestrians on sidewalks) and on-street bike infrastructure $(101 \mathrm{~km})$. Cycling infrastructure in other municipalities and the main routes connecting these with Bogotá are not included in Figure 2. 


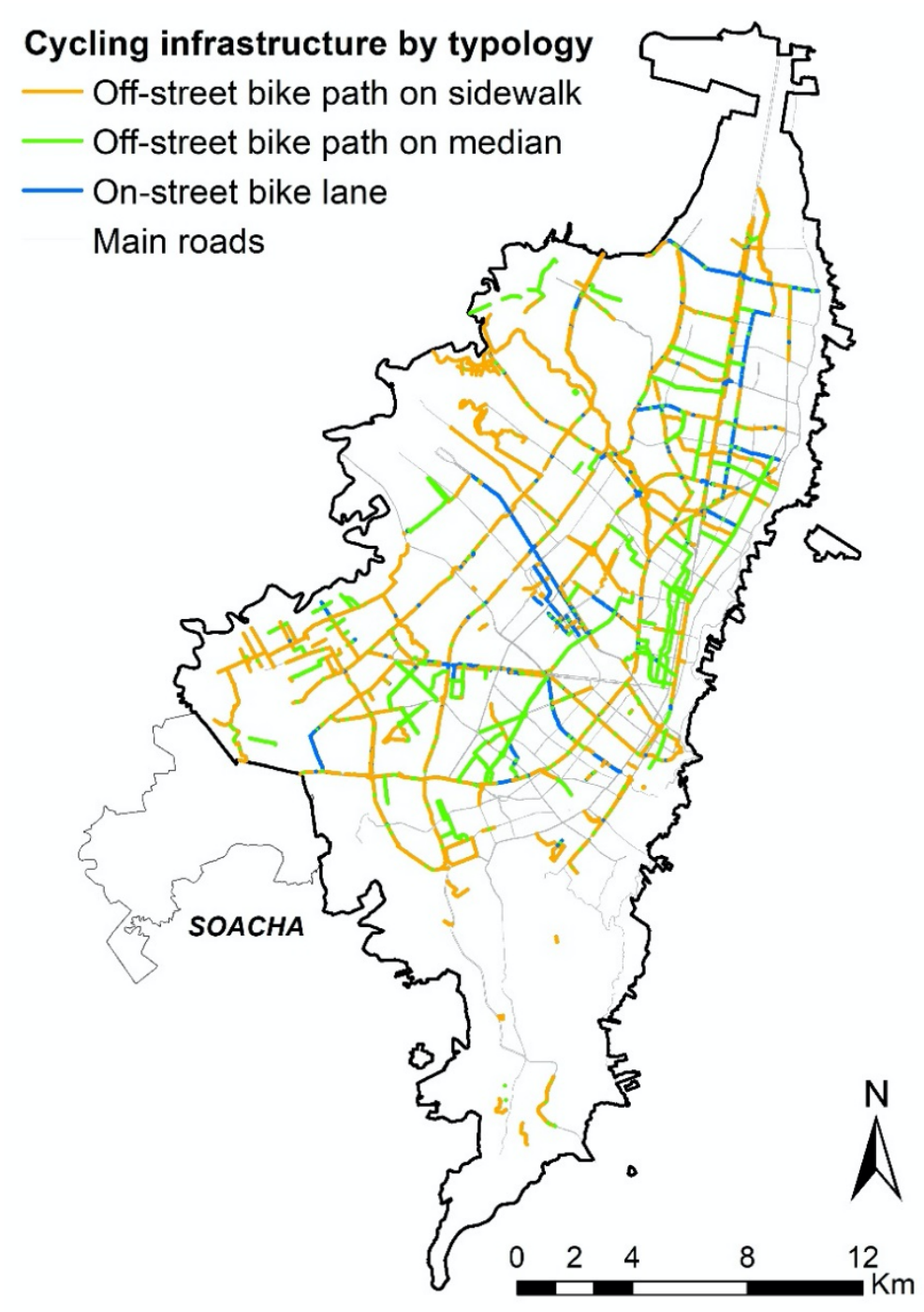

Figure 2 Bogotá cycling infrastructure in 2015 by typology

\section{Methodology}

This section describes data and methods used to estimate clustering, accessibility, and equality metrics applied to cyclists in Bogotá and Soacha. Available data of a sample of bicycle trips from the HTS for work or study purposes was analyzed and clustered. We use bicycle travel network distance as a proxy of cyclists' travel impedance related to individual trips. The clustering methodology to classify cyclists into statistically different groups is explained, followed by the 
process of estimating the impedance function for each group. Finally, we describe and discuss the appropriateness and relevance of inequality indicators used for assessing accessibility between clusters.

\subsection{Dataset}

A sample of 28,213 households from Bogotá's HTS 2015 includes information about travel patterns and socioeconomic characteristics of respondents. From this data, 147,251 trips on working days were gathered, out of which 9,260 were made by bicycle. Due to limitations of the dataset about spatial representativeness and socioeconomic information, the survey sample was analyzed without considering expansion factors. In addition to bicycle trips in Bogotá, trips with Soacha as origin or destination were also included given its overall social, functional, and spatial relationships with Bogotá (Oviedo Hernandez and Dávila, 2016). The sample of trips was further reduced to home-based trips having work or study as travel purposes, resulting in 968 observations. All these trips have as origin and destination available HTS georeferenced points within the Bogotá and Soacha limits, which together comprise the main supply of job and study opportunities in the region.

Information on job location was obtained from the Chamber of Commerce of Bogotá. 23,473 blocks with at least one job position were rasterized into $100 \times 100 \mathrm{~m}$ cells. Hence, the number of opportunities for workplaces is the number of active jobs in the cell corresponding to the individual's reported destination. Elementary schools were not considered as potential destinations since only $1.6 \%$ of bicycle trips were made by people aged 18 or less. Opportunities for high education correspond to the number of enrolled students in the second semester of 2015 at each institution. To this end, the estimations consider 155 geolocations of 109 high education 
institutions that were processed in the same way as jobs using data from a Ministry of Education report for Bogotá.

\subsection{Bicycle travel distance}

To have an objective estimation of impedance, measured as a function of travel distances for the HTS sample, we used origin and destination trip coordinates georeferenced for bicycle trips. Although individual self-reported travel time was available (the survey asked them to report the nearest trip time in 5-min time intervals), we prefer to use travel distance due to the inaccurate human perception of time (Rietveld, 2002).

Accordingly, it was assumed that cyclists would prefer the shortest route to reach their destinations for mandatory trips, given limited available time for diversions (Broach et al., 2012). Therefore, bicycle trip distances were calculated, giving precedence to the city's main roads when assigning the route to an OD pair, considering that $60 \%$ of cycling infrastructure is located alongside such road network. Distances were calculated using the Network Analyst extension of ArcGIS, considering a direction and turn unrestricted cyclable network composed by major, secondary, and local traffic roads, the dedicated cycling infrastructure network in 2015 (392 km), and pedestrian bridges. Absence of direction and turn restrictions are based on several characteristics of the city's infrastructure: all bike-paths were bidirectional by 2015 , cyclists could use sidewalks to circulate for short distances, ramp pedestrian bridges allow them to cross wide avenues and complex intersections, leading to short-distance left-turns.

\subsection{Cluster analysis}

Clustering individuals seek to segment modelling processes and better interpret results, and it characterizes a diverse group of individuals. Clustering allows identifying a reduced number of units of analysis with maximized statistical similarities within groups and dissimilarities between 
them. Also, statistical clustering methods allow researchers to estimate independent configuration of clusters relying only on data (Kaufman and Rousseeuw, 1990). Clustering individuals has been applied in transport studies to analyze specific groups users of non-motorized modes in relation to their mobility, access and experiences of public space, including mental health (Ahmed et al., 2017; Arranz-López et al., 2019; Huang et al., 2009; Huertas et al., 2020; Li et al., 2013; Pritchard et al., 2019; Salon, 2016).

To achieve more comprehensive accessibility results and equality analyses, we classified the data using both numerical (trip distance, vehicles per household ${ }^{1}$, household size, age) and categorical (SES, gender, job role, education level, driver license) variables describing individual, trip and household characteristics. K-prototypes clustering methodology was used to process both types of variables simultaneously when grouping the sample. This method combines K-means clustering minimizing the sum of square dissimilarities of numerical variables associated with individuals within the same cluster while maximizing similarities of categorical variables. Using R statistical software, the 968 bicycle trips were clustered using the K-prototypes methodology from the "clustMixType" package (Szepannek, 2018). A detailed description of the clustering methodology implemented is shown in Figure 3.

\footnotetext{
${ }^{1}$ Car and motorcycle.
} 


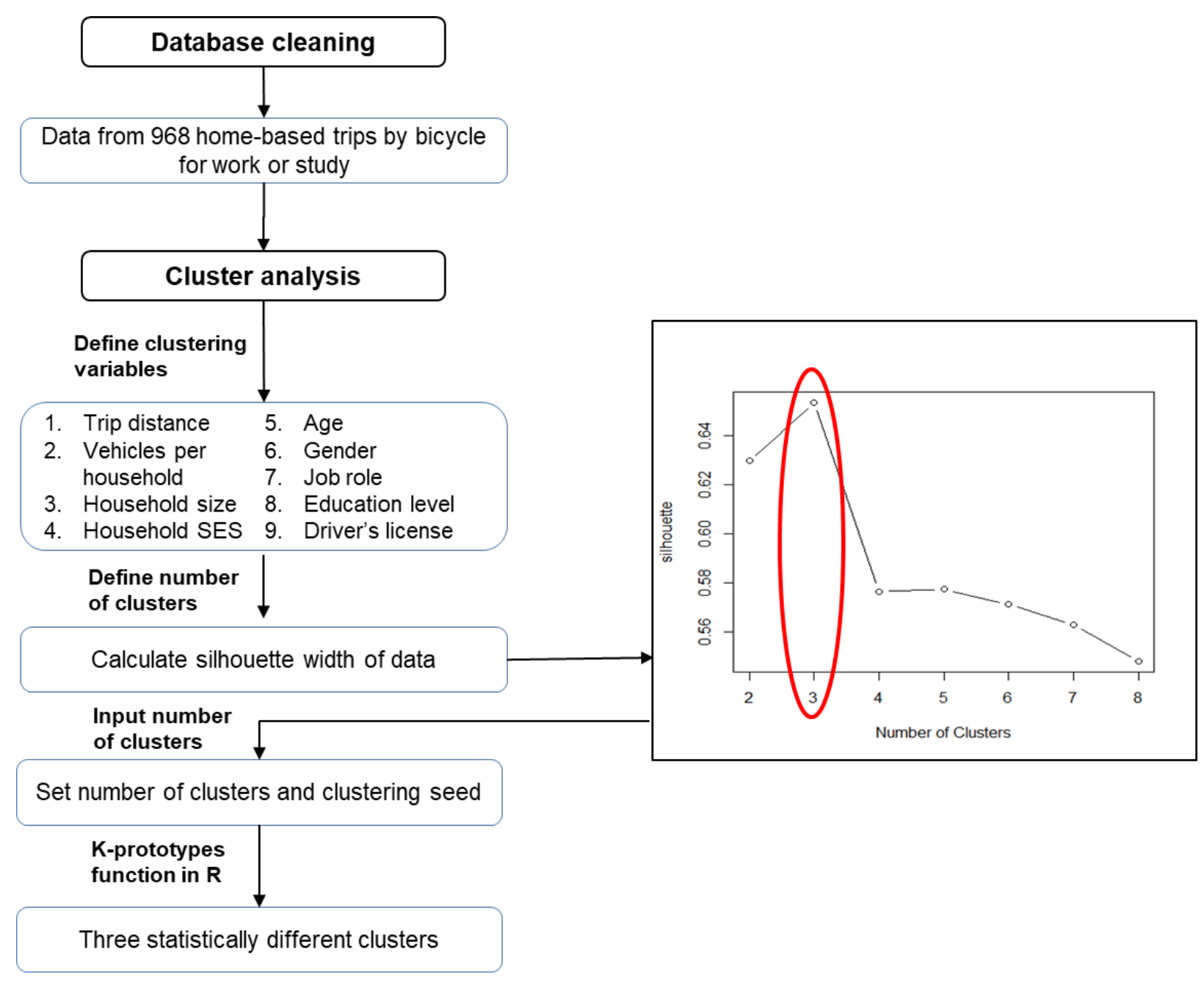

Figure 3 Clustering methodology

\subsection{Potential accessibility model}

We propose a potential accessibility formulation, estimating a negative exponential decay function. This distribution captures the behavior and propensity to travel as the distance to specific destinations increases or decreases (Iacono et al., 2010). Since this study aims to assess accessibility for mandatory trips, we use a potential measure from origin to destination (all available jobs and education slots, regardless if an individual is reaching it or not). The accessibility value formulation is shown in Equation (1), based on Guzmán et al. (2017).

$$
A_{i k}=\sum_{j=1}^{n} O_{j} * e^{-\beta_{k} X_{i j}}
$$


$A_{i k}=$ accessibility of home-based trip origin $i$ of cluster $k$

$O_{j}=$ job and study opportunities in $100 \times 100 \mathrm{~m}$ raster cell at destination $j$

$\beta_{k}=$ decay parameter of cyclists in cluster $k$

$X_{i j}=$ impedance (network distance) between origin $i$ and destination $j$

The decay parameter calibrated for each statistically different cluster allows to quantify perceived travel constraints related to each group's interaction with cycling for transport and is a sensitive variable influencing accessibility levels. The accessibility of an individual from cluster $k$ living at an origin $i$ is proportional to the number of opportunities in a nearby destination $j$ and the spatial interaction between $i$ and $j$. The latter formulation captures both transport and land use characteristics and assesses the effects of different policies on accessibility to jobs and study places within the cyclist population. The model transforms travel distance as a proxy for impedance into a measurable number of reachable opportunities and, as the decay parameters are clustered, it takes into account information such as gender, education level, income level, occupation, and household characteristics.

\subsection{Inequality evaluation}

Inequality indicators were used to identify disparities in potential accessibility by comparing the relative accessibility values of identified clusters. Lorenz curves and Gini indices, where 0 stands for perfect equality (i.e., all individuals have the same accessibility levels) and 1 corresponds to perfect inequality (i.e. one individual holds all the accessibility while the rest has no accessibility), were estimated for each cluster and the total sample of cyclists, seeking to compare the potential accessibility distribution between clusters and the overall cyclist sample. As argued in the introduction, this approach is consistent with recent research exploring the quantification of disparities between groups sharing differences of income (Ben-Elia and 
Benenson, 2019; Cao and Hickman, 2019; Lope and Dolgun, 2020; Oviedo and Guzman, 2020; Welch and Mishra, 2013). The equality metrics selected for this paper are complementary, reflecting different degrees and scales of inequality. While Lorenz curves enable a disaggregated understanding of the effects of differences across socioeconomic, geographical, and transportdriven distributions, Gini indices serve as an indication of the overall degree of inequality in accessibility. These estimations are further complemented by the use of Palma ratio, which focuses on the differences between the bottom of the distribution and those at the top, highlighting not only the quantitative differences between rich and poor, but providing evidence on its moral dimension of justice (Pereira et al., 2017). Using Palma's formulation of the ratio between the top $10 \%$ of the income distribution to the bottom $40 \%$, the estimation gives a measurable and comparable value to the marked socio-spatial segregation of urban structures in Latin America, which place wealthier populations in a literal better position to access opportunities and accumulate further wealth.

These indicators also serve to describe horizontal equality -or the even distribution of resources to all members of society-, and vertical equality -which targets socially disadvantaged groups- which can both inform policies and instruments (Delbosc and Currie, 2011). These scaleindependent indicators are easy to interpret and have powerful implications for decision-making and project evaluations with a social focus.

\section{Results}

Table 1 shows descriptive statistics of the sample of individuals who reported at least one bicycle trip for any purpose. Given the lack of specific information on household income, SES was used as a proxy. Then, we classified those cyclists living in SES 1 and 2 as low-SES; 3 and 4 for middle- 
SES, and 5 and 6 for the high-SES group. The sample has predominantly men of the low-SES group. However, the sample shows an increasing number of middle and high-SES groups that are also using the bicycle to commute (28\%). Most of these middle and high-SES cyclists seem to respond to high congestion levels and poor quality of service of public transport (Garcia-Suarez et al., 2018). Cyclists' households consist mostly of three or four people, and less than $5 \%$ have access to at least one car or motorcycle. In general, a high proportion of cyclists who work are employees, followed by independent workers.

Table 1 Cyclists' sample household and individual descriptive statistics

\begin{tabular}{|c|c|c|c|c|c|}
\hline \multicolumn{3}{|c|}{ Household information } & \multicolumn{3}{|c|}{ Individual information } \\
\hline & $\mathrm{n}$ & $\%$ & & $\mathrm{n}$ & $\%$ \\
\hline Household size & & & Gender & & \\
\hline 1 & 240 & 5.3 & Women & 1,165 & 25.8 \\
\hline 2 & 545 & 12.1 & Men & 3,348 & 74.2 \\
\hline 3 & 1,056 & 23.4 & Age & & \\
\hline 4 & 1,304 & 28.9 & $<18$ & 74 & 1.6 \\
\hline 5 & 847 & 18.8 & $18-34$ & 1,077 & 23.9 \\
\hline$>6$ & 521 & 11.5 & $35-55$ & 2,150 & 47.6 \\
\hline Socioeconomic strata (SES) & & & $>55$ & 1,212 & 26.9 \\
\hline 1 (Low SES) & 387 & 8.6 & Main activity & & \\
\hline 2 (Low SES) & 2,839 & 62.9 & Work & 3,378 & 74.9 \\
\hline 3 (Middle SES) & 1,129 & 25.0 & Study & 143 & 3.2 \\
\hline 4 (Middle SES) & 140 & 3.1 & Retired & 258 & 5.7 \\
\hline 5 (High SES) & 11 & 0.2 & Looking for a job & 105 & 2.3 \\
\hline 6 (High SES) & 7 & 0.2 & Other (housewife. unemployed) & 629 & 13.9 \\
\hline Cars in household & & & Role in job & & \\
\hline 0 & 4,272 & 94.7 & Boss & 40 & 0.9 \\
\hline 1 & 230 & 5.1 & Independent & 1,231 & 27.3 \\
\hline 2 & 10 & 0.2 & Employee & 2,131 & 47.2 \\
\hline$>2$ & 1 & 0.0 & Domestic worker & 31 & 0.7 \\
\hline Motorcycles in household & & & Other (casual laborer. farm worker) & 1,080 & 23.9 \\
\hline 0 & 4,326 & 95.9 & Education level & & \\
\hline 1 & 173 & 3.8 & None & 80 & 1.8 \\
\hline 2 & 11 & 0.2 & Kindergarten & 564 & 12.5 \\
\hline$>2$ & 3 & 0.1 & Primary school & 1,738 & 38.5 \\
\hline Bicycles in household & & & Middle school & 1,504 & 33.3 \\
\hline 1 & 3,432 & 76.0 & Professional & 524 & 11.6 \\
\hline 2 & 664 & 14.7 & Postgraduate & 103 & 2.3 \\
\hline 3 & 247 & 5.5 & Driver's license & & \\
\hline 4 & 110 & 2.4 & No license & 3,027 & 67.1 \\
\hline \multirow[t]{3}{*}{$>4$} & 60 & 1.3 & Car license & 1,046 & 23.2 \\
\hline & & & Motorcycle license & 233 & 5.2 \\
\hline & & & Other (bus/truck license) & 207 & 4.6 \\
\hline
\end{tabular}




\subsection{Clustering and cyclists' segmentation analysis}

After implementing the K-prototypes clustering method, three groups were obtained. Out of the nine variables used (Figure 3), three variables controlled cluster formation: gender, SES, and vehicles per household. Clustering silhouette widths account for an average of 0.65 indicating an accurate statistical cluster configuration. Based on the estimations, the resulting clusters are middle-low SES men (cluster 1), low-SES men (cluster 2), and women (cluster 3). All clusters are similar in terms of trip distances and age distribution. Descriptive statistics at the cluster level and t-tests between cluster variables are shown in Table 2. Figure 4 shows the trip origins and destinations for each identified cluster. 


\section{Cluster 1: Middle-low SES Men}

Cluster 2: Low SES Men Cluster 3: Low SES Women
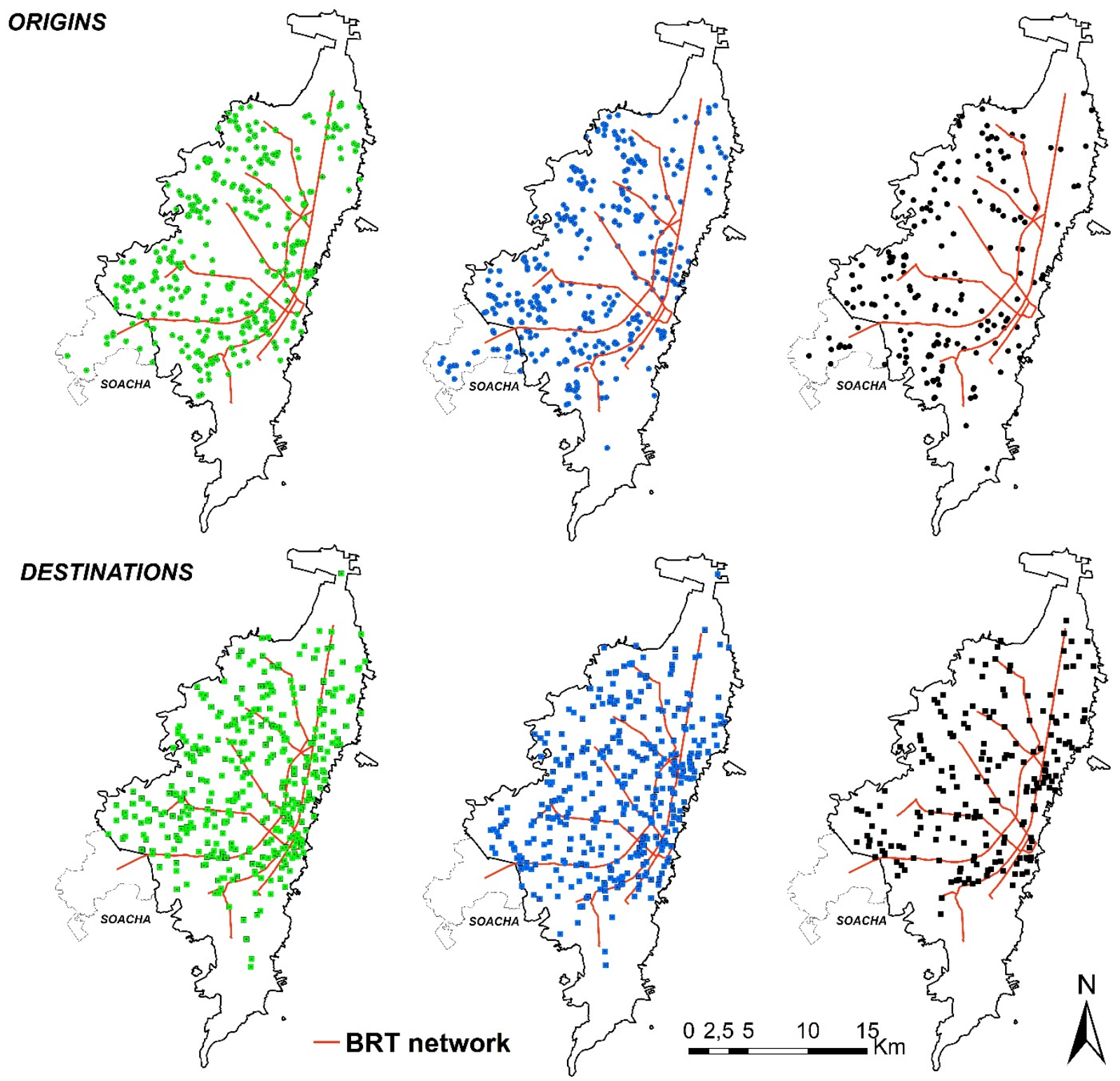

Figure 4 Cluster trip origins and destinations

Results for other travelers suggest this categorization is only representative among cyclists. In other modes, the composition of the sample enables the inclusion of other representative groups not reflected in our analysis. Due to the limitations of the dataset and the novelty in relation to the study of cyclist accessibility as opposed to the focus on motorized travel in previous research (see Guzman et al. (2018)), findings are centered on accessibility in this user group. 
Table 2 Cluster descriptive statistics

\begin{tabular}{|c|c|c|c|c|c|c|c|c|c|}
\hline & \multicolumn{2}{|c|}{$\begin{array}{l}\text { Cluster } 1 \\
\text { Middle-low } \\
\text { SES men }\end{array}$} & \multicolumn{2}{|c|}{$\begin{array}{c}\text { Cluster } 2 \\
\text { Low SES } \\
\text { men }\end{array}$} & \multicolumn{2}{|c|}{$\begin{array}{l}\text { Cluster } 3 \\
\text { Women }\end{array}$} & $\begin{array}{c}\mathrm{C} 1 \text { vs } \mathrm{C} 2 \\
\text { t-test }\end{array}$ & $\begin{array}{c}\text { C1 vs } \\
\text { C3 t-test } \\
\end{array}$ & $\begin{array}{c}\text { C2 vs } \\
\text { C3 t-test }\end{array}$ \\
\hline \multicolumn{10}{|l|}{ Cluster info } \\
\hline Cluster size & \multicolumn{2}{|c|}{417} & \multicolumn{2}{|c|}{395} & \multicolumn{2}{|c|}{202} & & & \\
\hline Avg silhouette width & \multicolumn{2}{|c|}{0.46} & \multicolumn{2}{|c|}{0.55} & \multicolumn{2}{|c|}{0.69} & & & \\
\hline $\begin{array}{l}\text { Trip and household variables for } \\
\text { clustering }\end{array}$ & Mean & St.D. & Mean & St.D. & Mean & St.D. & $\mathrm{p}$-value ${ }^{\mathrm{a}}$ & $\mathrm{p}$-value ${ }^{\mathrm{a}}$ & $\mathrm{p}$-value ${ }^{\mathrm{a}}$ \\
\hline \multicolumn{10}{|l|}{ Trip characteristics } \\
\hline Trip distance $[\mathrm{km}]$ & 7.0 & 7.1 & 7.7 & 6.2 & 7.8 & 6.0 & 0.133 & 0.138 & 0.834 \\
\hline Average speed $[\mathrm{km} / \mathrm{h}]$ & 9.2 & - & 8.8 & - & 9.1 & - & & & \\
\hline \multicolumn{10}{|l|}{ Vehicles in household } \\
\hline Cars & 0.14 & 0.38 & 0.01 & 0.07 & 0.02 & 0.16 & $0.000 * * *$ & $0.000 * * *$ & 0.089 \\
\hline Motorcycles & 0.08 & 0.32 & 0.01 & 0.05 & 0.03 & 0.17 & $0.000 * * *$ & $0.007 * *$ & 0.027 \\
\hline \multicolumn{10}{|l|}{ Household size } \\
\hline People in household & 3.82 & 1.37 & 3.25 & 1.49 & 3.61 & 1.26 & $0.000 * * *$ & 0.070 & $0.001 * * *$ \\
\hline \multirow{2}{*}{$\begin{array}{l}\text { Socioeconomic variables for } \\
\text { clustering } \\
\text { Household socioeconomic } \\
\text { strata }\end{array}$} & \multicolumn{2}{|r|}{$\%$} & \multicolumn{2}{|r|}{$\%$} & \multicolumn{2}{|r|}{$\%$} & p-value & p-value & p-value \\
\hline & & & & & & & $0.000 * * *$ & $0.000 * * *$ & 0.475 \\
\hline Low SES & 186 & 44.6 & 272 & 68.9 & 128 & 63.4 & & & \\
\hline Middle SES & 175 & 42.0 & 110 & 27.9 & 67 & 33.2 & & & \\
\hline High SES & 56 & 13.4 & 13 & 3.3 & 7 & 3.5 & & & \\
\hline Age & & & & & & & $0.000 * * *$ & 0.772 & 0.023 \\
\hline$<18$ & 9 & 2.2 & 0 & 0.0 & 9 & 4.5 & & & \\
\hline $18-34$ & 65 & 15.6 & 108 & 27.3 & 34 & 16.8 & & & \\
\hline $35-55$ & 210 & 50.4 & 192 & 48.5 & 93 & 46.0 & & & \\
\hline$>55$ & 133 & 31.9 & 96 & 24.2 & 66 & 32.7 & & & \\
\hline Gender & & & & & & & 0.058 & $0.000 * * *$ & $0.000 * * *$ \\
\hline Male & 395 & 94.3 & 386 & 97.7 & 2 & 1.0 & & & \\
\hline Female & 22 & 5.7 & 9 & 2.3 & 200 & 99.0 & & & \\
\hline \multicolumn{10}{|l|}{ Job role } \\
\hline Employee & 262 & 62.8 & 252 & 63.8 & 161 & 79.7 & $0.000 * * *$ & $0.004 * *$ & $0.000 * * *$ \\
\hline Independent & 155 & 37.2 & 128 & 32.4 & 40 & 19.8 & 0.154 & $0.000 * * *$ & $0.002 * *$ \\
\hline Employer/Boss & 0 & 0.0 & 15 & 3.8 & 1 & 0.5 & $0.000 * * *$ & 0.318 & $0.001 * * *$ \\
\hline \multicolumn{10}{|l|}{ Education level } \\
\hline None & 5 & 1.2 & 2 & 0.5 & 6 & 3.0 & 0.106 & 0.340 & 0.049 \\
\hline Kindergarten & 19 & 4.6 & 47 & 11.9 & 29 & 14.4 & $0.000 * * *$ & $0.001 * * *$ & 0.504 \\
\hline Primary school & 125 & 30.0 & 157 & 39.7 & 82 & 40.6 & $0.003^{*}$ & $0.009 * *$ & 0.842 \\
\hline High school & 134 & 32.1 & 130 & 32.9 & 68 & 33.7 & 0.877 & 0.497 & 0.584 \\
\hline Professional & 134 & 32.1 & 59 & 14.9 & 17 & 8.4 & $0.000 * * *$ & $0.000 * * *$ & $0.005 * *$ \\
\hline Post-graduate & 0 & 0.0 & 0 & 0.0 & 0 & 0.0 & NA & NA & NA \\
\hline \multicolumn{10}{|l|}{ Driver's license } \\
\hline No license & 89 & 21.3 & 388 & 98.2 & 192 & 95.0 & $0.000 * * *$ & $0.000 * * *$ & 0.046 \\
\hline Car license & 253 & 60.7 & 4 & 1.0 & 4 & 2.0 & $0.000 * * *$ & $0.000 * * *$ & 0.691 \\
\hline Motorcycle license & 36 & 8.6 & 2 & 0.5 & 0 & 0.0 & $0.000 * * *$ & $0.000 * * *$ & 0.158 \\
\hline $\begin{array}{l}\text { Other (bus/truck } \\
\text { license) }\end{array}$ & 39 & 9.4 & 1 & 0.3 & 6 & 3.0 & $0.000 * * *$ & $0.005 * *$ & $0.009 * *$ \\
\hline
\end{tabular}

Significance level: $* * * 0.1 \%, * * 1 \%$, and $* 5 \%$ 
Cluster 1 includes cyclists from predominantly low (44.6\%) and middle-SES levels (42.0\%). Cyclists in this cluster commute $7.0 \mathrm{~km}$ on average, $1.2 \mathrm{~km}$ less than the city's average for bicycle trips $(8.2 \mathrm{~km})$. Cluster 1 includes cyclists who are mostly independent workers and do not have a defined work schedule. Cluster 2 are cyclists living in low-SES residential areas and travelling an average distance of $7.7 \mathrm{~km}$. This group is comprised mainly of low-income residents with a high-school education. This cluster includes workers 18 years old and above, who are predominantly employees. Cluster 3 represents women who have similar socioeconomic and trip characteristics to men of Cluster 2, and who do not show significant differences in terms of availability of vehicles in the household, driver's license, and level of education. Roughly $95 \%$ of individuals from both Cluster 1 and 2 do not have a driver's license and have low motorization rates $(<0.03 \mathrm{veh} /$ household $)$. This constrains people from the clusters from commuting by private motorized modes, suggesting they may be captive cyclists. Cluster 3 shows an over-representation of women of low-SES, which suggests a much larger number of women who cycle from lower SES households than men. Women travel on average $7.8 \mathrm{~km}$ and are predominantly employees that completed high school.

Cluster 1 may be considered as 'rational cyclists' because they have more access than the other two clusters to private vehicles. Nearly $60.7 \%$ of individuals in Cluster 1 have a car driver's license and $8.6 \%$ of them have a motorcycle driving license. This group chooses to commute by bicycle despite having the choice of using private motorized modes, evidencing clear travel behavior differences between men from cluster 1 and cluster 2 .

Figure 5 shows the average travel distance for each cluster. These values were calculated using an inverse distance weighting method which interpolates values of points scattered in the territory. Blank spaces within the limits of the study area indicate a lack of data. Cyclists from 
Cluster 1 have a more homogeneous spatial distribution concerning travel distance, while commuter cyclists from Cluster 2 (low-SES men) tend to live in the periphery, making trips above $8 \mathrm{~km}$, similar to Cluster 3 (women). Most cyclists in Cluster 2 are in areas with high population density, which correlates with the low-SES population. Destinations are homogeneously distributed in the city for all three clusters, with a slightly higher concentration in the city center, explaining the high distance values for people living in the west and southern areas.

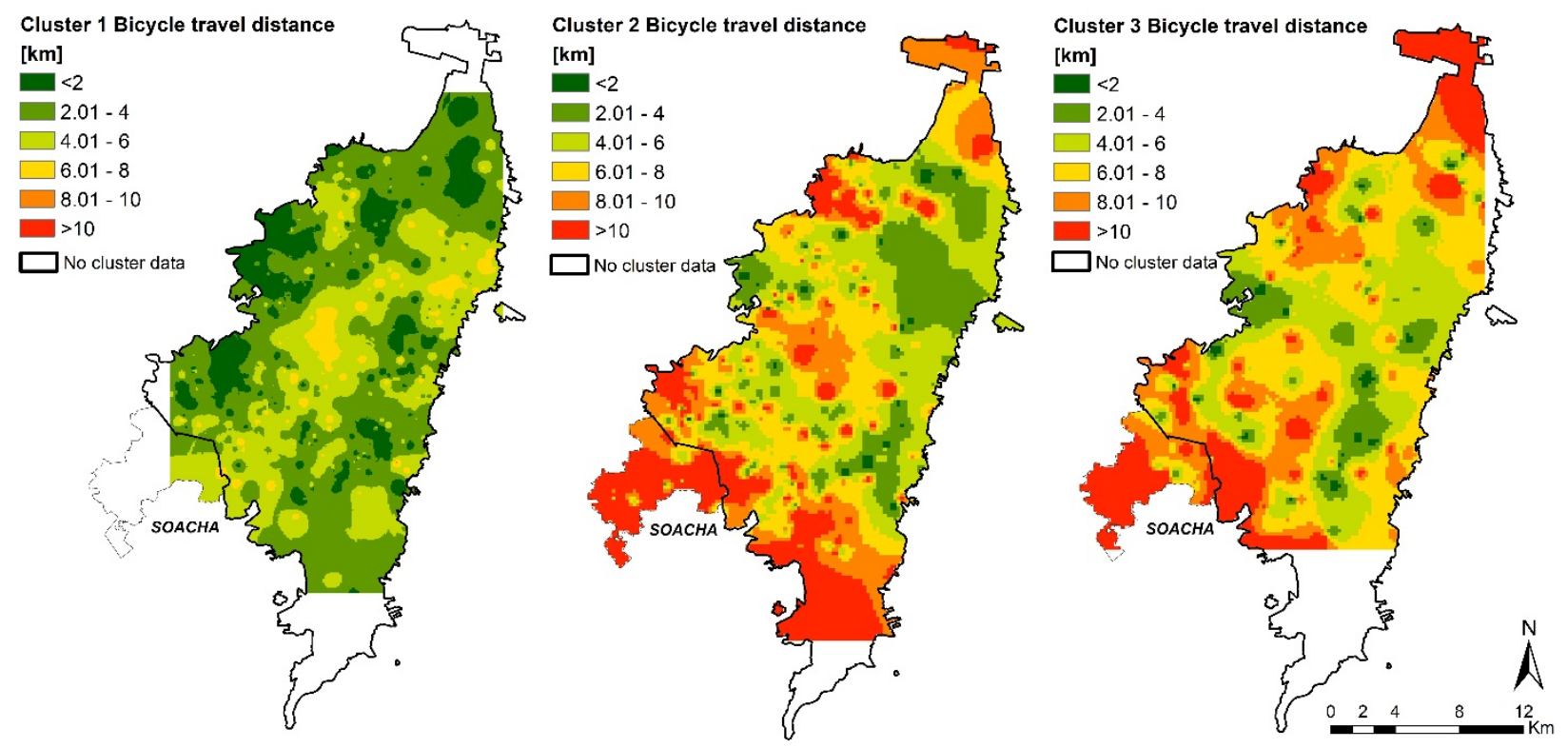

Figure 5 Average bicycle travel distance by cluster

Besides SES and education level, significant differences between clusters are primarily associated with travel frequency and access to cycling infrastructure. Table 3 shows travel frequency, inter-modality with public transport, and access to cycling infrastructure access across clusters. 
Table 3 Travel behavior and location characteristics of cyclists in clusters

\begin{tabular}{|c|c|c|c|c|c|c|c|c|c|}
\hline \multirow{4}{*}{$\begin{array}{l}\text { Travel frequency } \\
\text { Total daily bicycle trips (all } \\
\text { purposes) }\end{array}$} & \multicolumn{2}{|c|}{$\begin{array}{c}\text { Cluster 1 } \\
\text { Middle-low } \\
\text { SES men } \\
\end{array}$} & \multicolumn{2}{|c|}{$\begin{array}{c}\text { Cluster } 2 \\
\text { Low-SES } \\
\text { men } \\
\end{array}$} & \multicolumn{2}{|c|}{$\begin{array}{c}\text { Cluster } 3 \\
\text { Women }\end{array}$} & \multirow[t]{2}{*}{$\begin{array}{c}\mathrm{C} 1 \text { vs C2 } \\
\text { t-test }\end{array}$} & \multirow{2}{*}{$\begin{array}{c}\begin{array}{c}\text { C1 vs C3 } \\
\text { t-test }\end{array} \\
\text { p-value }\end{array}$} & \multirow[t]{2}{*}{$\begin{array}{c}\mathrm{C} 2 \text { vs } \mathrm{C} 3 \\
\text { t-test } \\
\end{array}$} \\
\hline & Mean & St.D. & Mean & St.D. & Mean & St.D. & & & \\
\hline & 2.22 & 0.81 & 2.17 & 0.67 & 2.12 & 0.51 & $0.041^{*}$ & 0.139 & 0.84 \\
\hline & $\mathrm{n}$ & $\%$ & $\mathrm{n}$ & $\%$ & $\mathrm{n}$ & $\%$ & & p-value ${ }^{a}$ & \\
\hline $\begin{array}{l}\text { Intermodal trip } \\
\text { Used public transport on the } \\
\text { same trip }\end{array}$ & 10 & 2.5 & 7 & 1.8 & 3 & 1.5 & 0.692 & 0.545 & 0.791 \\
\hline Otherwise & 407 & 97.5 & 388 & 98.2 & 199 & 98.5 & & & \\
\hline $\begin{array}{l}\text { Cycling infrastructure access } \\
\text { Household is within } 500- \\
\text { meter buffer } \\
\text { of a cycling infrastructure }\end{array}$ & 312 & 74.5 & 246 & 61.8 & 125 & 61.3 & $0.000 * * *$ & $0.000 * * *$ & 0.797 \\
\hline Otherwise & 105 & 25.5 & 149 & 38.2 & 77 & 38.7 & & & \\
\hline
\end{tabular}

Significance level: $* * * 0.1 \%, * * 1 \%$, and $* 5 \%$

Cyclists from Cluster 1 have a statistically higher average bicycle trip frequency compared to Cluster 2. People classified in Cluster 1 have statistically higher access to cycling infrastructure than those in clusters 2 and 3. Furthermore, there are no differences between clusters related to reaching public transport by bicycle. Clusters 2 and 3 have the lowest access to cycling infrastructure (using a $500 \mathrm{~m}$ buffer from the household). This represents an issue concerning the disproportion of cycling and public transport infrastructure in low-SES areas where there is a higher potential of use due to low motorization rates (Ortegon-Sanchez and Oviedo Hernandez, 2016), as is shown in Table 3.

\subsection{Cyclists' accessibility}

Table 4 shows decay parameters for each cluster with their goodness-of-fit indicators. These parameters were calibrated for each cluster using $800 \mathrm{~m}$-intervals as they presented the best fit for the exponential distribution function. The $\beta_{k}$ parameter in Eq. (1) for each $k$ cluster is significant at $99 \%$ confidence level. Cluster 3 has the highest negative coefficient, accounting for greater 
sensitivity to travel distance. This is partly explained by the predominant peripheral residential location of individuals and high travel distances, as shown in Figure 5. Also, the differences in the decay factor of Cluster 3 compared to the other two clusters are in line with statistical differences between men and women associated with environmental and infrastructure-related characteristics when riding a bicycle (Abasahl et al., 2018). Differences in coefficients between clusters 1 and 2 indicate that wealthier men have lower negative decay factors showing less sensitivity to travel distance than men living in lower SES. This formulation is a powerful resource to estimate the disposition of population groups to spend time for reaching desired opportunities.

Table 4 Distance decay function and average accessibility by cluster

\begin{tabular}{|c|c|c|c|c|c|c|}
\hline \multirow[b]{3}{*}{$\begin{array}{l}\text { Cluster } 1 \\
\text { Middle-low SES } \\
\text { men }\end{array}$} & \multicolumn{5}{|c|}{ Distance decay function models } & \multirow{2}{*}{$\begin{array}{l}\text { Potential accessibility to work and study } \\
\text { regarding the total average }\end{array}$} \\
\hline & Beta coef. & t-statistic & $\mathrm{p}$-value & F-statistic & Adj $R^{2}$ & \\
\hline & -0.281 & -8.280 & $0.000 * * *$ & 68.565 & 0.538 & $126.0 \%$ \\
\hline $\begin{array}{l}\text { Cluster } 2 \\
\text { Low-SES men }\end{array}$ & -0.343 & -9.182 & $0.000 * * *$ & 84.317 & 0.630 & $65.7 \%$ \\
\hline $\begin{array}{l}\text { Cluster } 3 \\
\text { Women }\end{array}$ & -0.408 & -6.034 & $0.000 * * *$ & 36.411 & 0.463 & $106.7 \%$ \\
\hline
\end{tabular}

Table 4 also shows the ratio between each cluster's total potential accessibility and the total cyclist population average. Results show that there is an uneven distribution in access to opportunities between cyclists. Cluster 1 has 1.26 times the average cyclist accessibility, while Cluster 2 (i.e., low-SES men) stands for only $65.7 \%$ of the average accessibility. Despite Cluster 3 having the highest negative distance decay coefficient, it has slightly higher accessibility than the overall average $(106.7 \%)$.

Figure 6 shows the spatial distribution of accessibility to work and study places by cluster. Accessibility for Cluster 1 is higher in the high-concentration zones of jobs and high-education places, and clusters 2 and 3 have lower accessibility values and are located farther from the opportunities. Although the lowest accessibility levels correspond to Cluster 2, this cluster has 
better geographical coverage of low accessibility values $(<25)$ than Cluster 3 . Women present two points of high accessibility values near the BRT network, suggesting good potential for intermodal trips reaching the city center. Cycling captivity among individuals in clusters 2 and 3 forces them to travel slightly longer distances, obtaining low concentrations of relative accessibility in areas farther away from where opportunities are concentrated. For example, accessibility values in Soacha Bogotá are less than 25 for all three clusters, revealing vast differences in accessibility between those who commute by bicycle living out and inside Bogotá limits.
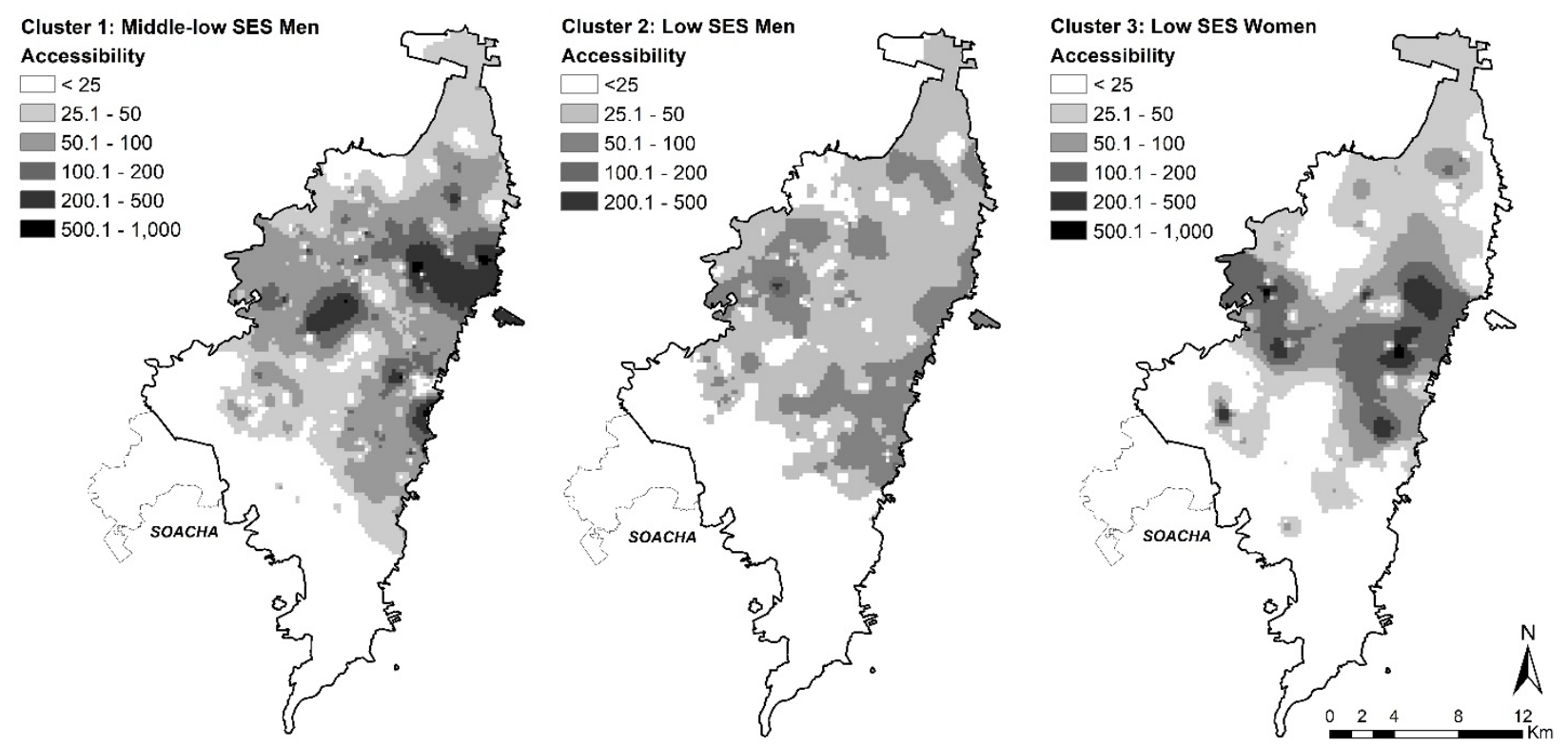

Figure 6 Average accessibility to work and study places by cluster

Distributions of accessibility values by cluster are shown in Figure 7. The overall accessibility distribution suggests that Cluster 1 has, on average, higher accessibility than the other two clusters, partly given short distances travelled. Despite Cluster 3 having the lowest average accessibility value, results suggest higher relative accessibility compared to the overall average than Cluster 2 due to the presence of individuals with very high accessibility values in the group (i.e., outliers that are identified spatially as black points in Figure 6 and numerically in Figure 7). 


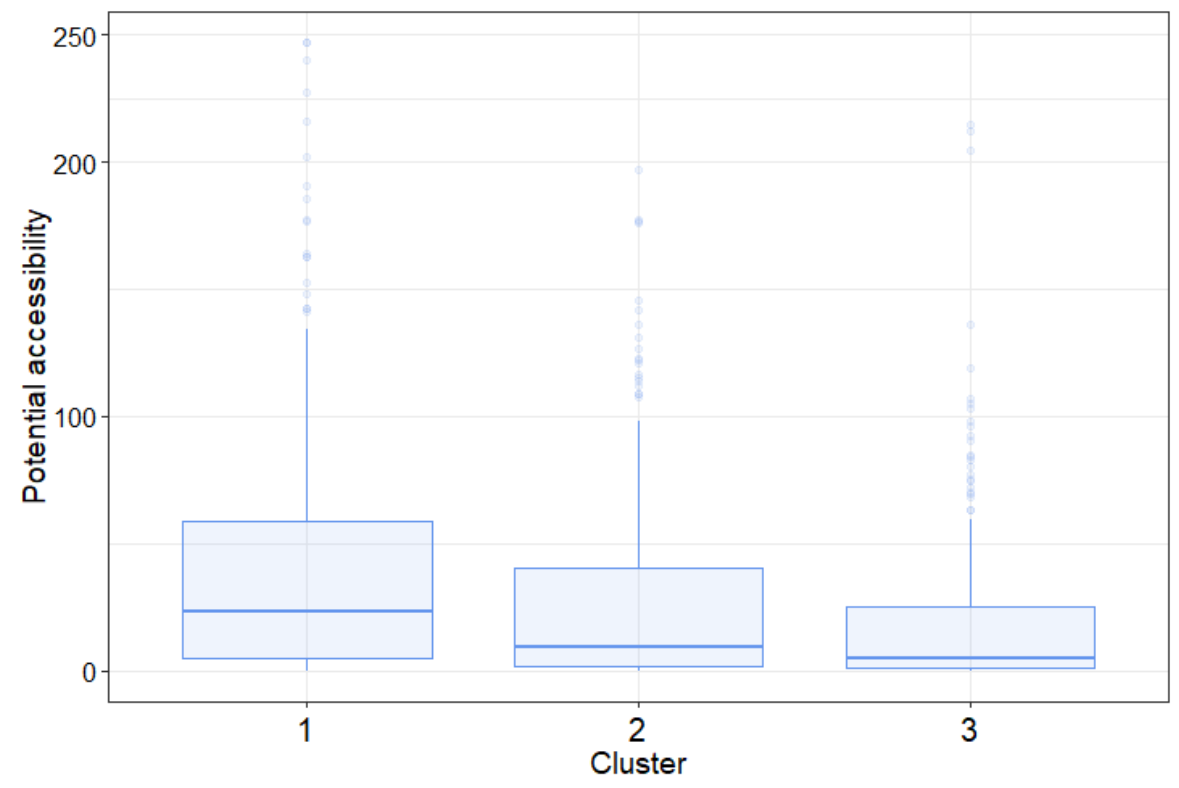

Figure 7 Accessibility values by cluster

Providing access to safe cycle paths among the low-SES population may have positive outcomes in accessibility measures and reduce accessibility gaps between user profiles. This is conditioned to improving trip conditions (i.e., road safety) for low-SES cyclists (Houde et al., 2018; Tucker and Manaugh, 2018), particularly women (Grudgings et al., 2018; Mackintosh and Norcliffe, 2007).

\subsection{Cycling inequality}

Lorenz curves were calculated for the entire sample and each cluster, comparing the proportion of cyclists and the proportion of accessibility. Figure 8 (left) shows a poor distribution of accessibility, which is encapsulated by a Gini index for the entire cyclist population of 0.718 . Figure 8 (right) shows potential accessibility distributed by cluster. Clusters 1 and 2 have a similar distribution in accessibility compared to Cluster 3. As Clusters 1 and 2 intersect at the $78 \%$ of cyclists' threshold, there are no clear differences in accessibility distribution between the two groups (with very similar Gini indices of 0.678 and 0.671 , respectively). Cluster 3 has a higher 
Gini index (0.811), suggesting a more unequal accessibility distribution for women who use the bicycle, with $90 \%$ of the population potentially accessing only $30 \%$ of the opportunities.
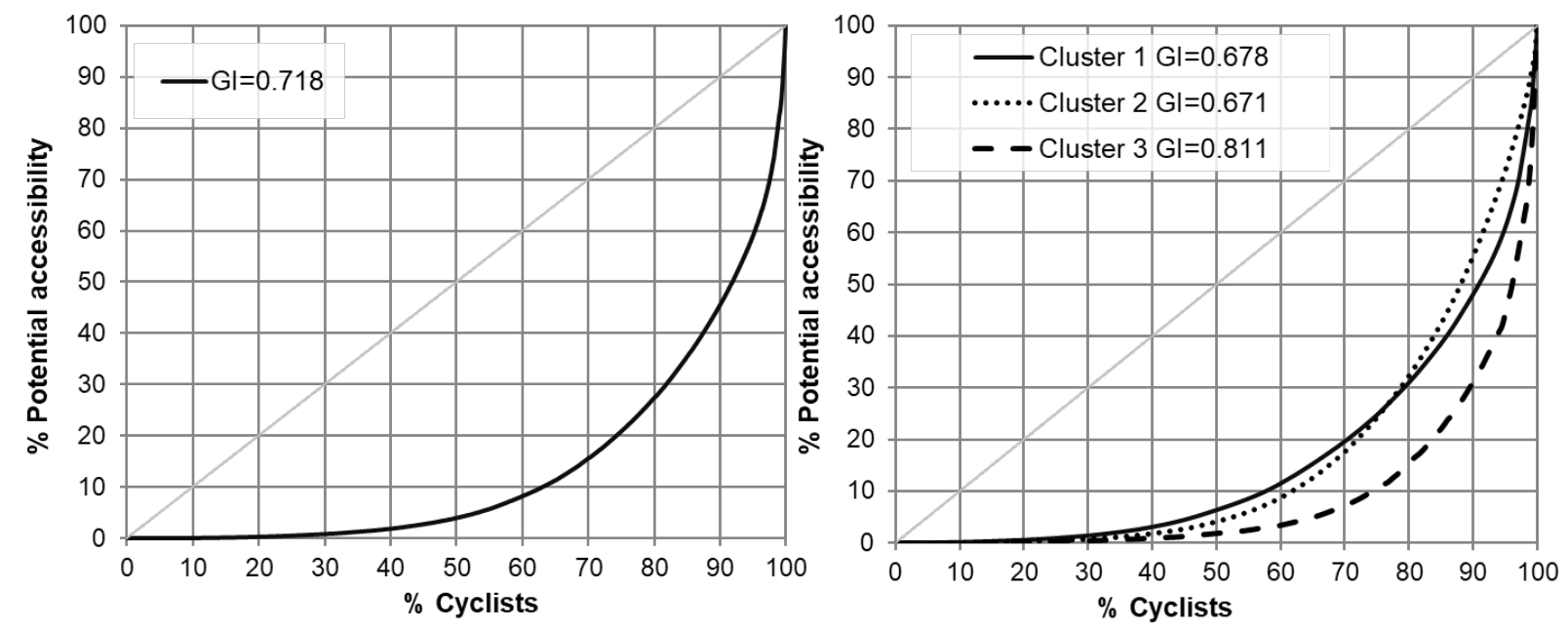

Figure 8 Lorenz curves of the total sample of cyclists (left) and by cluster (right)

The analysis of inequality in accessibility sheds light on gaps between cyclists with different socioeconomic characteristics. Half of the cyclist population has access to less than $10 \%$ of the opportunities. Such gaps between clusters have been previously found to be influenced by factors such as household location and vehicle access (both cars and bicycles) (Arranz-López et al., 2018; Pritchard et al., 2019). Travel impedance is larger for women than for men, and the distribution of accessibility among Cluster 3 is highly unequal. Overall, the results suggesting a poor accessibility distribution among cyclists, and that this inequality is amplified when considering differences in gender between cycling commuters.

Residence location, vehicle ownership, and gender are therefore explanatory factors in accessibility inequalities in cycling. The Palma ratio is 30.0 , indicating that the top $10 \%$ cyclists with the higher accessibility concentrate approximately 30 times more access to opportunities than the bottom $40 \%$ of cyclists. This ratio is highly controlled by residential location since almost $90 \%$ of cyclists live in a 100x100 m area with a job and study offer a density of 2,000 opportunities $/ \mathrm{km}^{2}$. 
The clear differences in accessibility explain why accessibility values are predominantly higher near the city center only for Cluster 1 .

\section{Discussion}

The methodology in this article is replicable in contexts where databases on bicycle trips and socioeconomic information at the individual and household level are available. The K-prototypes clustering methodology provides an additional perspective on the profiles and social identities of different types of cyclists in a given context.

Results of accessibility by clusters make visible inequalities between cyclist groups. The clustering data process streamlines the definition of cyclists' profiles and how these influence their ability to reach income-generating opportunities. Clustering enables researchers to incorporate the effects of differences in social identities (e.g. gender), spatial inequalities (e.g. residence location), and socioeconomic determinants (e.g. vehicle access) in the distribution of accessibility. Methodologically, this implies a contribution to applied accessibility studies in similar settings as it enables statistically valid classifications of standard datasets for assessments of inequalities.

Although travel distances in Bogotá are relatively short (between 7 and $8 \mathrm{~km}$ ), its centralized urban structure in relation to the location of employment and education opportunities in less than $20 \%$ of the urban area implies disproportionately longer travel distances for lowincome citizens compared to wealthier groups. Such conditions are endemic of many cities in the Global South and lead to marked spatial and socioeconomic divides, which translate into transport disadvantage and systematic exclusion. Long average travel distances for the low-income population are clear examples of urban conditions in which walking becomes an unfeasible alternative for reaching essential opportunities for increasing economic capital, which also 
suggests that the categories found for cyclists do not necessarily apply to other transport mode users, including walking commuters.

Disproportionate differences in accessibility to job and study places are strongly correlated with high levels of inequality for the bicycle when compared to motorized modes as suggested by previous research in the same context (Guzman et al., 2017). In an environment where low-income people are excluded from the economic activities by high transport costs, results suggest limited potential for the bicycle to address problems of accessibility on its own. Findings also suggest that women, who travel less on average by bicycle and have lower cycling infrastructure access than middle-low SES men, having also lower accessibility to opportunities. This implies gender disparities in the ability of men and women to benefit from the bicycle as a transport mode when traveling in the city. The analysis by cluster confirms that, as with road infrastructure and public transport provision, there is a disproportionate concentration of cycling infrastructure in wealthier and highly attractive areas of the city in line with the logic of spatial inequality in the provision of transport infrastructure suggested by earlier studies (Oviedo Hernandez and Dávila, 2016). Such disparities in access to infrastructure for safe and convenient travel by bicycle may also help explain the similarities in the Gini index estimations for Clusters 1 and 2, suggesting a significant role of infrastructure, or lack thereof in reproducing accessibility inequalities.

\section{Conclusions}

Our research contributes to a growing body of literature on non-motorized accessibility analyses constrained by conceptual, methodological and empirical issues. Small sample sizes and lack of bicycle-specific information in household travel surveys are relevant limitations for cycling research. Distributional analyses are relevant in this regard as they add a social dimension to the 
analysis of cycling beyond conventional sustainability and health arguments and serve as a case for improving information regarding travel behavior of cyclists and its main drivers. Despite limitations in the sample, we identified clusters marked by differences of class and gender, which suggest the need to explore other social identities (e.g. ethnicity) to inform better decision-making and research in cycling. Our findings support the argument that social inclusion through the bicycle (Rodríguez et al., 2017) is possible since data collection mechanisms are implemented, and communication channels are improved to better-understand this population and launch strategies to improve their access to opportunities.

Evidence in this paper provides strong arguments to explore further the potential of the built environment and urban structures in cities such as Bogotá in reproducing accessibility inequalities. There is a need for more diverse accessibility measures that incorporate competition factors and controls for vehicle availability of individuals, which could unearth implications for reaching opportunities by bicycle vis a vis motorized accessibility to the same opportunities.

Disparities in accessibility within the same population using an affordable and costeffective choice such as the bicycle invites to explore alternatives for improving bicycle accessibility. For instance, investments in bicycle parking facilities in public transport stations can improve accessibility and inclusion in the economic activities of low-income residents. New cityscale programs oriented to promote bicycle use targeting mainly school children have the potential to increase cycling in the medium and long term and reduce the accessibility and uptake gaps between genders and income levels evidenced in the research.

Our evidence supports the need for more equality-centered policies such as cross-subsidies, targeted infrastructure provision, and support for bicycle purchases in areas of social and physical disadvantage. The use of accessibility as a policy target can help to question traditional criteria for 
public investment and policy delivery in cities such as Bogotá, improving the distributional effects of cycling policies.

\section{Author contribution statement}

Daniel Rosas-Satizábal: Conceptualization, Methodology, Data curation, Formal Analysis, Visualization, Writing- Original draft preparation. Luis A. Guzman: Conceptualization, Methodology, Investigation, Formal Analysis, Writing- Original draft preparation. Daniel Oviedo: Conceptualization, Methodology, Formal Analysis, Validation, Writing- Original draft preparation.

\section{Declaration of competing interest}

The authors declare that they have no known competing financial interests or personal relationships that could have appeared to influence the work reported in this paper.

\section{Funding sources}

This research did not receive any specific grant from funding agencies in the public, commercial, or not-for-profit sectors. 


\section{References}

Abasahl, F., Kelarestaghi, K.B., Ermagun, A., 2018. Gender gap generators for bicycle mode choice in Baltimore college campuses. Travel Behav. Soc. 11, 78-85. https://doi.org/10.1016/j.tbs.2018.01.002

Abley, S., Transportation, A., Limited, C., Consultants, A., 2010. Measuring accessibility and providing transport choice. Aust. Inst. Traffic Plan. Manag. 15. https://doi.org/10.1016/j.socscimed.2008.11.033

Ahmed, F., Rose, G., Jakob, C., Hoque, R., 2017. Examination of Clusters for Better Understanding of Commuter Cyclists' Travel Behavior: Insights from Longitudinal Panel Survey. Transp. Res. Rec. J. Transp. Res. Board 2665, 40-50. https://doi.org/10.3141/266505

Anable, J., 2005. "Complacent Car Addicts"; or "Aspiring Environmentalists"? Identifying travel behaviour segments using attitude theory. Transp. Policy 12, 65-78. https://doi.org/10.1016/j.tranpol.2004.11.004

Arranz-López, A., Soria-Lara, J.A., Pueyo-Campos, Á., 2019. Social and spatial equity effects of non-motorized accessibility to retail. Cities 86, 71-82. https://doi.org/10.1016/j.cities.2018.12.012

Arranz-López, A., Soria-Lara, J.A., Witlox, F., Páez, A., 2018. Measuring relative non-motorized accessibility to retail activities. Int. J. Sustain. Transp. 0, 1-13. https://doi.org/10.1080/15568318.2018.1498563

Ben-Elia, E., Benenson, I., 2019. A spatially-explicit method for analyzing the equity of transit 
commuters' accessibility. Transp. Res. Part A Policy Pract. 120, 31-42. https://doi.org/10.1016/j.tra.2018.11.017

Blondiau, T., Van Zeebroeck, B., Haubold, H., 2016. Economic Benefits of Increased Cycling. Transp. Res. Procedia 14, 2306-2313. https://doi.org/10.1016/j.trpro.2016.05.247

Broach, J., Dill, J., Gliebe, J., 2012. Where do cyclists ride? A route choice model developed with revealed preference GPS data. Transp. Res. Part A Policy Pract. 46, 1730-1740. https://doi.org/10.1016/j.tra.2012.07.005

Cantillo-García, V., Guzman, L.A., Arellana, J., 2019. Socioeconomic strata as proxy variable for household income in transportation research. Evaluation for Bogotá, Medellín, Cali and Barranquilla. Dyna 86, 258-267. https://doi.org/10.15446/dyna.v86n211.81821

Cao, M., Hickman, R., 2019. Understanding travel and differential capabilities and functionings in Beijing. Transp. Policy 83, 46-56. https://doi.org/10.1016/j.tranpol.2019.08.006

DANE, 2017. Encuesta multipropósito 2017. Departamento Administrativo Nacional de Estadisticas [WWW Document]. URL https://www.dane.gov.co/index.php/estadisticas-portema/pobreza-y-condiciones-de-vida/encuesta-multiproposito/encuesta-multiproposito-2017 (accessed 5.31.19).

De Vos, J., Mokhtarian, P.L., Schwanen, T., Van Acker, V., Witlox, F., 2016. Travel mode choice and travel satisfaction: bridging the gap between decision utility and experienced utility. Transportation (Amst). 43, 771-796. https://doi.org/10.1007/s11116-015-9619-9

Delbosc, A., Currie, G., 2011. Using Lorenz curves to assess public transport equity. J. Transp. Geogr. 19, 1252-1259. https://doi.org/10.1016/j.jtrangeo.2011.02.008 
Garcia-Suarez, C., Rivera-Perez, L., Rodriguez-Valencia, A., 2018. Defining Transmilenio Users' Value and Satisfaction Through Lean Thinking Approach. Transp. Res. Rec. J. Transp. Res. Board. https://doi.org/10.1177/0361198118787363

Grengs, J., 2015. Nonwork Accessibility as a Social Equity Indicator. Int. J. Sustain. Transp. 9, 114. https://doi.org/10.1080/15568318.2012.719582

Grisé, E., El-Geneidy, A., 2017. Where is the happy transit rider? Evaluating satisfaction with regional rail service using a spatial segmentation approach. Transp. Res. Part A Policy Pract. 0-1. https://doi.org/10.1016/j.tra.2017.11.005

Grudgings, N., Hagen-Zanker, A., Hughes, S., Gatersleben, B., Woodall, M., Bryans, W., 2018. Why don't more women cycle? An analysis of female and male commuter cycling modeshare in England and Wales. J. Transp. Heal. 10, 272-283. https://doi.org/10.1016/j.jth.2018.07.004

Guzman, L.A., Bocarejo, J.P., 2017. Urban form and spatial urban equity in Bogota, Colombia. Transp. Res. Procedia 25, 4491-4506. https://doi.org/10.1016/j.trpro.2017.05.345

Guzman, L.A., Oviedo, D., 2018. Accessibility, affordability and equity: Assessing' pro-poor' public transport subsidies in Bogotá. Transp. Policy 68, 37-51. https://doi.org/10.1016/j.tranpol.2018.04.012

Guzman, L.A., Oviedo, D., Cardona, R., 2018. Accessibility changes: Analysis of the integrated public transport system of Bogotá. Sustain. 10. https://doi.org/10.3390/su10113958

Guzman, L.A., Oviedo, D., Rivera, C., 2017. Assessing equity in transport accessibility to work and study: The Bogotá region. J. Transp. Geogr. 58, 236-246. 
https://doi.org/10.1016/j.jtrangeo.2016.12.016

Handy, S., van Wee, B., Kroesen, M., 2014. Promoting Cycling for Transport: Research Needs and Challenges. Transp. Rev. 34, 4-24. https://doi.org/10.1080/01441647.2013.860204

Houde, M., Apparicio, P., Séguin, A.M., 2018. A ride for whom: Has cycling network expansion reduced inequities in accessibility in Montreal, Canada? J. Transp. Geogr. 68, 9-21. https://doi.org/10.1016/j.jtrangeo.2018.02.005

Huang, L., Stinchcomb, D.G., Pickle, L.W., Dill, J., Berrigan, D., 2009. Identifying Clusters of Active Transportation Using Spatial Scan Statistics. Am. J. Prev. Med. 37, 157-166. https://doi.org/10.1016/j.amepre.2009.04.021

Huertas, J.A., Palacio, A., Botero, M., Carvajal, G.A., Laake, T. Van, Higuera-mendieta, D., Cabrales, S.A., Guzman, L.A., Sarmiento, O., Medaglia, A., 2020. Level of traffic stressbased classification: A clustering approach for Bogotá Colombia. Transp. Res. Part D Transp. Environ. 85, 1-17. https://doi.org/10.1016/j.trd.2020.102420

Iacono, M., Krizek, K.J., El-Geneidy, A., 2010. Measuring non-motorized accessibility: issues, alternatives, and execution. J. Transp. Geogr. 18, 133-140. https://doi.org/10.1016/j.jtrangeo.2009.02.002

Kaplan, S., Popoks, D., Prato, C.G., Ceder, A., 2014. Using connectivity for measuring equity in transit provision. J. Transp. Geogr. 37, 82-92. https://doi.org/10.1016/j.jtrangeo.2014.04.016

Kaufman, L., Rousseeuw, P.J., 1990. Finding Groups in Data: An Introduction to Cluster Analysis, Wiley Series in Probability and Statistics.

Li, Z., Wang, W., Yang, C., Ragland, D.R., 2013. Bicycle commuting market analysis using 
attitudinal market segmentation approach. Transp. Res. Part A Policy Pract. 47, 56-68. https://doi.org/10.1016/j.tra.2012.10.017

Lope, D.J., Dolgun, A., 2020. Measuring the inequality of accessible trams in Melbourne. J. Transp. Geogr. 83, 102657. https://doi.org/10.1016/j.jtrangeo.2020.102657

Mackintosh, P.G., Norcliffe, G., 2007. Men, Women and the Bicycle: Gender and Social Geography of Cycling in the Late Nineteenth-Century, in: Horton, D., Rosen, P., Cox, P. (Eds.), Cycling and Society. Ashgate, Hampshire, England, pp. 153-178.

McNeil, N., 2011. Bikeability and the 20-min Neighborhood. Transp. Res. Rec. J. Transp. Res. Board 2247, 53-63. https://doi.org/10.3141/2247-07

Ohnmacht, T., Maksim, H., Bergman, M., 2009. Mobilities and inequality: making connections.

Ortegon-Sanchez, A., Oviedo Hernandez, D., 2016. Assessment of the potential for modal shift to non-motorized transport in a developing context: Case of Lima, Peru. Res. Transp. Econ. 60, 3-13. https://doi.org/10.1016/j.retrec.2016.05.010

Oviedo, D., Guzman, L.A., 2020. Revisiting Accessibility in a Context of Sustainable Transport: Capabilities and Inequalities in Bogotá. Sustainability 12, 4464. https://doi.org/10.3390/su12114464

Oviedo Hernandez, D., Dávila, J.D., 2016. Transport, urban development and the peripheral poor in Colombia - Placing splintering urbanism in the context of transport networks. J. Transp. Geogr. 51, 180-192. https://doi.org/10.1016/j.jtrangeo.2016.01.003

Pereira, R.H.M., Schwanen, T., Banister, D., 2017. Distributive justice and equity in transportation. Transp. Rev. 37, 170-191. https://doi.org/10.1080/01441647.2016.1257660 
Pritchard, J.P., Moura, F., Silva, J. de A. e, Martinez, L.M., 2014. Spatial Analysis of Transportation-related Social Exclusion in the Lisbon Metropolitan Area. Procedia - Soc. Behav. Sci. 111, 440-449. https://doi.org/10.1016/j.sbspro.2014.01.077

Pritchard, J.P., Tomasiello, D.B., Giannotti, M., Geurs, K., 2019. Potential impacts of bike-andride on job accessibility and spatial equity in São Paulo, Brazil. Transp. Res. Part A Policy Pract. 121, 386-400. https://doi.org/10.1016/j.tra.2019.01.022

Pucher, J., Buehler, R., Bassett, D.R., Dannenberg, A.L., 2010. Walking and cycling to health: A comparative analysis of city, state, and international data. Am. J. Public Health 100, 19861992. https://doi.org/10.2105/AJPH.2009.189324

Rios, R.A., Taddia, A., Pardo, C., Lleras, N., 2015. Ciclo-inclusión en América Latina y el Caribe: Guía para impulsar el uso de la bicicleta [WWW Document]. Inter-American Dev. Bank. URL http://publications.iadb.org/handle/11319/6808 (accessed 4.12.18).

Rodríguez, M., Pinto Ayala, A.M., Páez, D., Ortiz, M.Á., Bocarejo, J.P., Oviedo, D., Saud, V., 2017. La Bicicleta: Vehículo hacia la equidad: Recomendaciones para la equidad, acceso e inclusión social en la promoción del uso de la bicicleta en América Latina y el Caribe. [WWW Document]. Inter-American Dev. Bank. URL https://publications.iadb.org/es/publicacion/14072/la-bicicleta-vehiculo-hacia-la-equidadrecomendaciones-para-la-equidad-acceso-e (accessed 12.4.18).

Rosas-Satizábal, D., Rodriguez-Valencia, A., 2019. Factors and policies explaining the emergence of the bicycle commuter in Bogotá. Case Stud. Transp. Policy 7, 138-149. https://doi.org/10.1016/J.CSTP.2018.12.007 
Saghapour, T., Moridpour, S., Thompson, R.G., 2017. Measuring cycling accessibility in metropolitan areas. Int. J. Sustain. Transp. 11, 381-394. https://doi.org/10.1080/15568318.2016.1262927

Sallis, J.F., Frank, L.D., Saelens, B.E., Kraft, M.K., 2004. Active transportation and physical activity: Opportunities for collaboration on transportation and public health research. Transp. Res. Part A Policy Pract. 38, 249-268. https://doi.org/10.1016/j.tra.2003.11.003

Salon, D., 2016. Estimating pedestrian and cyclist activity at the neighborhood scale. J. Transp. Geogr. 55, 11-21. https://doi.org/10.1016/j.jtrangeo.2016.06.023

Szepannek, G., 2018. clustMixType: User-Friendly Clustering of Mixed-Type Data in R. R J. 10, 200. https://doi.org/10.32614/rj-2018-048

Tucker, B., Manaugh, K., 2018. Bicycle equity in Brazil: Access to safe cycling routes across neighborhoods in Rio de Janeiro and Curitiba. Int. J. Sustain. Transp. 12, 29-38. https://doi.org/10.1080/15568318.2017.1324585

Welch, T.F., Mishra, S., 2013. A measure of equity for public transit connectivity. J. Transp. Geogr. 33, 29-41. https://doi.org/10.1016/j.jtrangeo.2013.09.007 